\title{
Would you like to donate your reward points today? Mental accounting and checkout charity
}

\author{
Min Chung $\operatorname{Han}^{1}$ (D)
}

Received: 26 March 2021 / Accepted: 15 September 2021 / Published online: 27 September 2021

(c) The Author(s), under exclusive licence to Springer-Verlag GmbH Germany, part of Springer Nature 2021

\begin{abstract}
Checkout charity is the solicitation of charitable donations from consumers during the checkout process via a cashier or computer automated system. Although checkout charity has become ubiquitous in the retail industry, consumers often felt pressured to donate and wished not to be asked to donate. How can we encourage consumers to donate when they encounter online checkout charity and make feel good about it? This study tried to address this question by identifying how online shoppers' attitudes and donation behavior could be influenced by donation payment method based on mental accounting. The result confirms that requesting a donation in reward points would enhance consumers' attitude toward the retailer and their intention to donate to an online checkout charity. This study provides important managerial implications for companies, charities, and practitioners regarding how they can improve their online checkout charity practice to increase donations and sales and garner the benefits of enhanced corporate image by aligning themselves with charities.
\end{abstract}

Keywords Checkout charity $\cdot$ Mental accounting $\cdot$ Reward points $\cdot$ Attitude . Purchase intention

\section{Introduction}

Companies and marketers have formed associations with charities to differentiate themselves from competitors, to enhance their corporate image, to boost sales, and to generate extensive publicity for businesses as well as causes (Austin, 2000; Polonsky \& Macdonald, 2000). Evidence suggests that companies' dedication to a good cause and a charity strongly influence consumers' perceptions of companies and their consumption behaviors. Consumers view companies that contribute to social causes more favorably than companies that do not (Till \& Nowak, 2000). Consumers

Min Chung Han

mihan@kean.edu

1 Kean University, 1000 Morris Avenue Union, New Jersey 07083, USA 
are more likely to purchase from brands that support social causes when price and quality were unchanged (Szykman et al. 2004). Furthermore, millennial consumers, the largest consumer group in U.S. history, are willing to pay more if the company supports social causes (Strauss \& Howe, 2000; Lantos, 2014; Youn \& Kim, 2008).

'Checkout charity' is one practice that has become ubiquitous in the retail industry. Checkout charity solicits charitable donations from consumers during the checkout process by either a sales associate (retail stores) or computer automated system (website or self-checkout kiosk) (Giebelhausen et al. 2017; Kinard \& Pardo, 2017). This practice has become one of the successful supports for charities as it raised more than $\$ 441$ million in 2016 and \$486 million in 2018 in the U.S., an increase of $10 \%$. For example, eBay has raised more than $\$ 69$ million for 66,000 charities from checkout charity campaign in 2018 alone (Engage for Good, 2020).

Despite its growing popularity, there have been some pitfalls associated with this practice. Consumers often felt pressured to donate and wished not to be asked to donate. Some confessed they donated to avoid feeling guilty rather than out of altruistic motivation (Good Scout, 2016; Roos, 2018). Some expressed doubt over corporations' authenticity, raising questions such as where the contributions are actually going, what percentage of donation goes to the intended cause, and whether the retailer itself was making any contribution to the charity (Murray, 2017). As a result, consumers donated less than $\$ 2$ per checkout transaction or $\$ 1.73$ annually for checkout donation (Charitynavigator, 2020; Obeng, et al. 2019). This leads to the question: How can we encourage consumers to donate more and make them feel positive about the companies?

Although checkout charity has become commonplace in retail shopping, much remains to be answered about the factors that influence the generation of favorable attitudes toward the company by online consumers and regarding how to improve online consumers' donation and purchase intentions. The extant literature has predominantly focused on checkout charity in offline retail settings (Giebelhausen et al. 2017, 2020; Kinard \& Pardo, 2017; Nakhata \& Dugan, 2017). Online settings, such as e-commerce website, have created a different environment. For example, there is no social pressure (e.g., sales associates), which has been overlooked even though e-commerce is a new norm coupled with advanced technology in the retail industry. More importantly, the literature has not yet addressed the question of how donation payment options impact the consumers' attitude toward the retailer and their donation behavior despite the prevalent use of alternative payment options such as reward points and miles for donation.

This research addresses the gap by identifying how online shoppers' attitudes and donation behavior could be influenced by donation payment options. By identifying the key decision factors influencing online consumers based on mental accounting, this study provides information as to how companies can improve their online checkout charity practices by increasing donation and sales as well as achieving the benefits of enhanced corporate image by aligning themselves with charities.

This study has a three-fold purpose: (1) to investigate whether types of donation payment options (e.g., reward points vs. money) would influence online consumers' attitude toward the company and their behavioral intention, (2) to understand whether the product price and types would influence shoppers' attitudes and 
donation intention of the online checkout charity campaign; and (3) to suggest the managerial implications for marketers to implement checkout charity campaigns successfully through their e-commerce platforms.

\section{Theoretical background and hypothesis}

\subsection{Checkout charity and cause-related marketing}

"Would you like to donate $\$ 1$ to support a children's charity today?" Some consumers reluctantly agree to donate $\$ 1$, and some consumers sheepishly smile and say, "Not today." Consumers frequently encounter such requests at grocery stores, convenience stores, supermarkets and, recently, online retail stores. This donation strategy has been coined as "checkout charity," which is a charitable donation campaign in which cashiers or self-service technologies solicit monetary donations from consumers during the payment (checkout) process (Giebelhausen et al. 2020; Kinard $\&$ Pardo, 2017). This practice has raised more than $\$ 5.3$ billion over three decades and raised \$486 million in 2018 for U.S. charities (Engage for Good, 2020). It is a vital source for many charities. For example, Children's Miracle Network Hospitals received more than $\$ 91$ million from checkout charity in 2018 alone (Engage for Good, 2020).

Checkout charity is a part of Cause-related Marketing (CrM), a commercial activity through which a partnership is formed by businesses and charities for mutual benefit to support good causes (Adkins, 2012; Barone et al. 2000; Varadarajan \& Menon, 1988). CrM is marketing activities that are characterized by engaging consumers in revenue generating transactions with a firm such as purchasing products or services and donating a specific amount to a designated nonprofit organization (Kotler \& Lee, 2005; Mullen, 1997; Varadarajan \& Menon, 1988). For instance, American Express, a CrM pioneer who coined the phrase in 1983, donated 1 cent to the Statue of Liberty Fund each time existing cardholders used their American Express card; the company contributed $\$ 1$ for every new card approved (Kelly, 1991). American Express witnessed a $28 \%$ increase in card usage during the campaign period compared to the same period a year before and contributed $\$ 1.7$ million to the Statue of Liberty Fund (Varadarajan \& Menon, 1988). Companies engage in CrM for several reasons, such as increasing sales, improving their corporate image, and enhancing consumer loyalty (Park et al. 2017; Varadarajan\& Menon, 1988). Consumers also experience a positive feeling (e.g., a warm glow) for being prosocial by participating in CrM (Chang \& Chu, 2020).

\subsection{Mental accounting}

Mental accounting is defined as "the set of cognitive operations used by individuals and households to organize, evaluate, and keep track of financial activities" (Thaler, 1999). People use mental accounting to make consumption choices such as what to buy and how much to save, which is often based on subjective criteria (Thaler, 1985, 
1999). Mental accounting assumes that the same amount of money may be perceived, organized, and interpreted differently by different people in a different context (Soman, 2004). For example, consumers believe the difference between $\$ 10$ and $\$ 20$ is much bigger than the difference between $\$ 1000$ and $\$ 1010$, irrespective of the actual amount difference (Thaler, 1999). Also, consumers often code advanced purchased items (e.g., concert tickets) as "free" rather than the actual cost when they consumed it later (Shafir \& Thaler, 2006).

Consumers show a greater willingness to spend money when the payment is decoupled from the purchase because equivalent money loss is not always interpreted as equivalently painful (Raghubir \& Srivastava, 2009). Thaler (1999) claimed that the credit card is the best decoupling device that separates payment from purchase. Credit card payment reduces the salience and vividness of the payment while paying in cash induces greater pain (Prelec \& Loewenstein, 1998). As cash payments accentuate the pain of paying and credit cards generate less pain, consumers tend to spend less when paying in cash than with credit cards (Thomas et al. 2011; Zellermayer, 1996).

Previous literature on the decoupling effect of the payment suggested that less vivid and more inert payment options elicit less pain of paying even when the payment modes are normatively equivalent (Raghubir \& Srivastava, 2008, 2009; Soman, 2001). Raghubir and Srivastava (2008) demonstrated that people spend more money when the amount of money was given as a gift certificate than when the equivalent amount is given in cash. The researchers argued that the emotionally inert modes of payment would feel like 'play money' or 'monopoly money' and make it easier for consumers to spend. Heath and Soll (1996) suggested that consumers set budgets for expense categories based on mental accounting and track expenses against their mental budget. This leads them to overconsume or underconsume depending on the categories. As such, a consumer may place cash or more vivid mode of payments into a mental account of "real money," whereas less vivid and emotionally more inert modes of payment go into a "play money" mental account (Raghubir \& Srivastava, 2009).

Consumers are more likely to spend money when it is unearned or unexpected, such as at a casino or from the lottery, rather than regular income or retirement saving withdrawals (Shefrin \& Thaler, 1988). For example, group of students who were given no information about reward money for participation in a study experiment spent more money when they got the unexpected money than students who knew they would be paid for their participation (Arkes et al. 1994). Consumers also consider a product that was given as part of promotion as "free" and the loss of the product does not bother them. For instance, when consumers received a ticket as part of "buy three, get one free" sales promotion, they think of the one ticket as 'free' and did not think they lost any money when they lost the fourth concert ticket (Liu \& Chiu, 2015).

Based on the mental accounting and the findings of aforementioned research, it is reasonable to expect that people would perceive reward points as 'play money' or 'monopoly money' instead of real money in their mental account because the payment mode is less vivid and more inert (Raghubir \& Srivastava, 2008, 2009; Soman, 2001). Furthermore, consumers are more likely to spend money and may not feel 
the same pain in parting from it when it is unearned or when they believe it was 'free' (Arkes et al. 1994; Liu \& Chiu, 2015). Therefore, consumers would be more favorable toward the online retailer that suggests donating and more likely to donate when the payment option is reward points that they earned through online shopping rather than the equivalent amount of money. This is because it is less painful to part with reward points and would feel like "play money" or "free." Thus, the following hypothesis is proposed:

H1 Suggesting a checkout donation in reward points will result in (a) more favorable attitude, (b) higher donation intention, and (c) higher purchase intention compared to a checkout donation in money.

Previous studies have shown that consumers do not always consider the same amount of money as equivalently valuable (Raghubir \& Srivastava, 2009; Soster et al. 2014). For example, consumers put more effort to save $\$ 5$ on a $\$ 50$ product purchase than to save $\$ 15$ on a $\$ 150$ product even though the percentage of saving was same (Thaler, 1980). Similarly, consumers were more willing to travel a farther distance to save $\$ 5$ when shopping for a lower price product than when shopping for a high price product (Tversky \& Kahneman, 1981). Evidently, the significance of small discounts is reduced and consumers become less sensitive to the amount of a discount with large expenditures such as cars (Tversky \& Kahneman, 1981). Strahilevitz (1999) argued that a consumer would find a small discount insignificant and would prefer to donate the same amount of money to a charity than getting a discount when purchasing high ticket item. On the other hand, when the donation amount is relatively high compared to the product price, consumers might think the company is taking credit for the good deed at the expense of consumers (Hajjat, 2003; Strahilevitz, 1999). This leads to a reduction in consumers' purchase intention because consumers dismiss the effort as insincere and opportunistic (Barone et al. 2007; Gupta \& Pirsch, 2006).

Based on the prior research, it is plausible to assume that consumers would be more positive toward the retailer and more likely to donate and purchase when they plan to buy an expensive product than the cheaper product because the donation amount is deemed less significant. Therefore, hypothesis 2 is proposed:

H2 Suggesting checkout donation with a higher price product will result in (a) more favorable attitude, (b) higher donation intention, and (c) higher purchase intention compared to a checkout donation with a lower price product.

Prior studies have shown that pain of payment affects the willingness to spend money (Prelec \& Loewenstein, 1998; Thomas et al. 2011) and the less salient and vivid payment methods reduce the pain (Raghubir \& Srivastava, 2008, 2009; Soman, 2001). Also consumers consider a small amount of discount to be insignificant and become less sensitive to the amount of money when purchasing expensive products (Strahilevitz, 1999). Considering that the reward points are more likely to be perceived as "free" and less salient than actual money, consumers may find 
parting from the reward points less painful and be less sensitive to the amount as it is not significant when purchasing high price products. Thus, it is plausible to assume that suggesting a checkout donation in reward points when purchasing a higher price product will amplify the consumers' positive attitude and behavioral intentions, resulting in higher donation and purchase intention. Hence, the hypothesis:

H3 Suggesting a checkout donation in reward points when purchasing a higher price product will result in (a) more favorable attitude, (b) higher donation intention, and (c) higher purchase intention compared to a checkout donation in money with a lower price product.

Shafir and Thaler (2006) suggested that consumers don't treat all their money as equal if the time of consumption is different than the time of purchase. For example, a bottle of wine that was purchased long ago would be perceived as free or saving money instead of the actual price of the wine. Consumers have forgotten the price by the time they consume it, so the wine seems free. Furthermore, the wine seems like an investment if the price has appreciated. Consumers tend to get more enjoyment from the consumption of previously purchased items because they feel as if they are consuming free products (Dunn \& Norton, 2013). Similarly, Prelec and Loewenstein (1998) found that consumers think that a vacation that has already been paid for is more enjoyable, as if it were free, because the pain associated with payment has already passed. Based on this, it is reasonable to expect that consumers would consider the previously earned and unused reward points as free and would be more likely to spend the points to donate. Thus, following hypothesis is proposed:

H4 Suggesting a checkout donation using previously earned reward points will result in (a) more favorable attitude, (b) higher donation intention, and (c) higher purchase intention compared to a checkout donation using future reward points.

Prior research has confirmed that consumers are more likely to donate when buying a hedonic product than a utilitarian one because of their feelings of guilt (Kinard \& Pardo, 2017; Strahilevitz, 1999; Strahilevitz \& Myers, 1998). Buying a non-necessary product for fun can increase consumers' guilt compared to a practical product. Zemack-Rugar et al. (2016) argued that consumers find the option of donating to a charity more appealing when buying a hedonic product because it is a way to lessen their feelings of guilt. Similarly, consumers perceived CrM more positively when they were informed that a certain portion of the product price would be donated to a charity when they purchased a hedonic product. However, no such effect was found when purchasing a utilitarian product (Baghi et al. 2010). Given that consumers are more likely to donate to reduce their guilt when purchasing hedonic product, this study proposes hypothesis as follows:

H5 Suggesting a checkout donation when purchasing a hedonic product will result in (a) more favorable attitude, (b) higher donation intention, and (c) higher purchase intention compared to a checkout donation with a utilitarian product. 
When consumers consume an item that was purchased previously, they have forgotten the price and the item seems free (Prelec \& Loewenstein, 1998; Shafir \& Thaler, 2006; Thaler, 1985). Prior findings suggested that consumers are more likely to donate when buying a hedonic product as a way to lessen their feelings of guilt (Baghi et al. 2010; Zemack-Rugar et al. 2016). It would be plausible to assume that consumers would find it easier to donate when they purchase a hedonic product so as to reduce their feelings of guilt and if the reward points were earned earlier and sit unused because they would feel as if the points are free. Therefore, pertaining to the role of mental accounting and hedonic products in consumer behavior, this study hypothesizes the following:

H6. Suggesting a checkout donation using previously earned reward points when purchasing a hedonic product will result in (a) more favorable attitude, (b) higher donation intention, and (c) higher purchase intention compared to a checkout donation using future reward points with a utilitarian product.

\section{Study 1}

Study 1 was designed to test hypotheses $1-3$. This study examined whether the option to donate reward points will elicit more a favorable attitude, higher donation intention, and higher purchase intention compared with the option to donate money as well as whether the level of product price would influence consumers' response in a checkout charity.

\section{Method}

\subsection{Participants}

Participants were recruited through Amazon Mechanical Turk (MTurk). This study used MTurk to distribute a survey based on the prior findings that MTurk provides a larger and more diverse sample that reflects actual population demographics (Berinsky et al. 2012; Schleider \& Weisz, 2015). A total of 207 online commerce users participated and 200 participants completed the online survey. Of these participants $(M=35.37)$ who completed the survey, $49.0 \%(n=98)$ were men, $51.0 \%(n=102)$ were women. For the age ranges, $25.5 \%$ of the respondents were aged $18-24,31.5 \%$ were aged $25-34,19.0 \%$ were $35-44,8.0 \%$ were $45-54$, and $13.0 \%$ were over 55 years old.

\subsection{Design}

This study chose an experimental design to control noise factors because there might be other factors that influence online shoppers' responses to checkout charity campaign. This study used a 2 (donation payment type: reward points vs. money) $\times$ 2 (product price level: high vs. low) factorial between-group experimental design. 


\subsection{Materials and procedure}

Four different online shopping checkout pages were created for this study. The checkout pages were designed using a fictitious charity "COVID19 Relief Foundation" without a specific company name to avoid pre-exposure brand name bias. Two different donation payment options were alternately presented for the same value: $\$ 5$ donation and 500 reward points. It was clearly indicated on the page that the 500 reward points were equal to $\$ 5$. The product (jeans) price appeared in two levels: high price $(\$ 250)$ and low price $(\$ 50)$. The price reflected the actual market price of the product. At the time the experiment was conducted, Levi's jeans regular price ranged from $\$ 59.50$ to $\$ 298$. This study chose $\$ 50$ and $\$ 250$ to reflect the price range. To prevent people from recognizing the specific brand name from the product image, a photo of a stack of folded jeans was used instead of a photo of one specific pair of jeans.

The online survey link was distributed on Amazon MTurk. All participants were required to read a short script about online shopping for a new pair of jeans. They were asked to imagine that they found the perfect jeans and started the checkout process. Once participants finished reading the script, they were randomly assigned to one of four checkout pages. One of the four checkout pages was presented randomly with its donation option as either money (\$5) or reward points (500 points) and product price high $(\$ 250)$ or low $(\$ 50)$. Participants then completed a questionnaire to measure their attitude, donation intention, and purchase intention.

\subsection{Measures}

This study adopted measurement scales from the existing literature. The attitude toward an online retailer was measured using six items on a seven-point Likert scale, ranging from 1 being "Strongly disagree" to 7 being "Strongly agree." Two items were adapted from Mitchell and Olson (1981) and four items were from Nan and Heo (2007). Respondents were asked "How well each of the following adjectives describes the retailer in the previous checkout page?" and presented adjectives such as "good" and "likeable." Donation intention (Bower \& Landreth, 2001; Putrevu \& Lord, 1994) was measured using four items on a seven-point Likert scale. Examples include, "I will likely to donate at the checkout page of the website I saw" and "I will consider donating at the checkout page of the website I saw." Purchase intention (Chandran \& Morwitz, 2005; Leonidou \& Skarmeas, 2017) was measured using four items on a seven-point Likert scale ranging from 1 being "Extremely low" to 7 being "Extremely high." Examples are, "If I were in the market for a product like this, the likelihood that I would buy this product is" and "If I were in the market for a product like this, the probability that I would purchase this product is."

All scales adopted for the study were assessed to examine internal consistency. Cronbach's $\alpha$ coefficients analysis was applied to all measurement items. Attitude toward an online retailer $(\alpha=0.963)$, donation intention $(\alpha=0.965)$, and purchase intention $(\alpha=0.98)$ all showed a Cronbach's $\alpha$ higher than $0.8(\alpha>0.8)$, which far exceeds 
the threshold deemed as good (Cortina, 1993). Thus, all items used met the reliability requirements.

\section{Results}

To test the hypotheses a 2 (donation payment: reward points vs. money) $\times 2$ (product price: high vs. low) two way ANOVA (analysis of variance) was conducted on the dependent variables: attitude toward the online retailer, donation intention, and purchase intention (Table1).

Hypothesis 1 expected that consumers would show more a favorable attitude (H1a), higher donation intention (H1b), and higher purchase intention (H1c) when the donation was suggested in reward points instead of money in a checkout charity. The result yielded a statistically significant main effect of donation payment type on attitude ( $\mathrm{F}(1$, $196)=4.73, p<0.05)$ and donation intention $(\mathrm{F}(1,196)=4.06, p<0.05)$. Mean attitude was $5.40(\mathrm{SD}=1.08)$ with reward points donation compared to $5.05(\mathrm{SD}=1.29)$ with money donation, supporting H1 (a). Mean donation intention was $4.41(\mathrm{SD}=1.91)$ with reward points donation compared to $3.86(\mathrm{SD}=1.94)$ with money donation, supporting $\mathrm{H} 1$ (b). However, there was no statistically significant main effect of donation payment type on purchase intention $(\mathrm{F}(1,196)=0.01, p>0.05)$, rejecting $\mathrm{H} 1$ (c).

$\mathrm{H} 2$ predicted that suggesting a checkout donation when purchasing a higher price product will result in more favorable attitude $(\mathrm{H} 2 \mathrm{a})$, higher donation intention $(\mathrm{H} 2 \mathrm{~b})$, and higher purchase intention $(\mathrm{H} 2 \mathrm{c})$ rather than purchasing a lower price item. A statistically significant difference was found for product price level on attitude $(\mathrm{F}(1,196)=12.45, p<0.05)$ and purchase intention $(\mathrm{F}(1,196)=47.85$, $p<0.05)$. Contrary to the hypothesis, however, the higher price product induced a less favorable attitude $(M=3.33, S D=2.11)$ than the lower price product $(M=5.17$, $\mathrm{SD}=1.59)$ and lower purchase intention $(\mathrm{M}=3.33, \mathrm{SD}=2.11)$ than purchase intention for the lower product price $(M=5.17, \mathrm{SD}=1.59)$, rejecting $\mathrm{H} 2$ (a) and $\mathrm{H} 2$ (c). No significant main effect was found for product price level on donation intention ( $\mathrm{F}$ $(1,196)=0.076, \mathrm{p}>0.05)$, thus not supporting $\mathrm{H} 2(\mathrm{~b})$.

$\mathrm{H} 3$ assumed there would be an interaction effect between donation payment type and product price level on attitude $(\mathrm{H} 3 \mathrm{a})$, donation intention $(\mathrm{H} 3 \mathrm{~b})$, and purchase intention $(\mathrm{H} 3 \mathrm{c})$. The two-way interaction effect was insignificant on attitude (F (1, $196)=2.363, \mathrm{p}>0.05)$, donation intention $(\mathrm{F}(1,196)=0.009, \mathrm{p}>0.05)$, and purchase intention $(\mathrm{F}(1,196)=0.813, \mathrm{p}>0.05)$. There was no significant difference in attitude, donation intention, and purchase intention when the donation was suggested in reward points and with purchasing a higher price product compared with money donation and a lower price product. Thus, H3 is not supported.

\section{Discussions}

The results of Study 1 showed that consumers are more likely to respond positively to checkout charity when a donation is suggested in reward points than money. Specifically, suggesting a donation in reward points elicited more favorable 


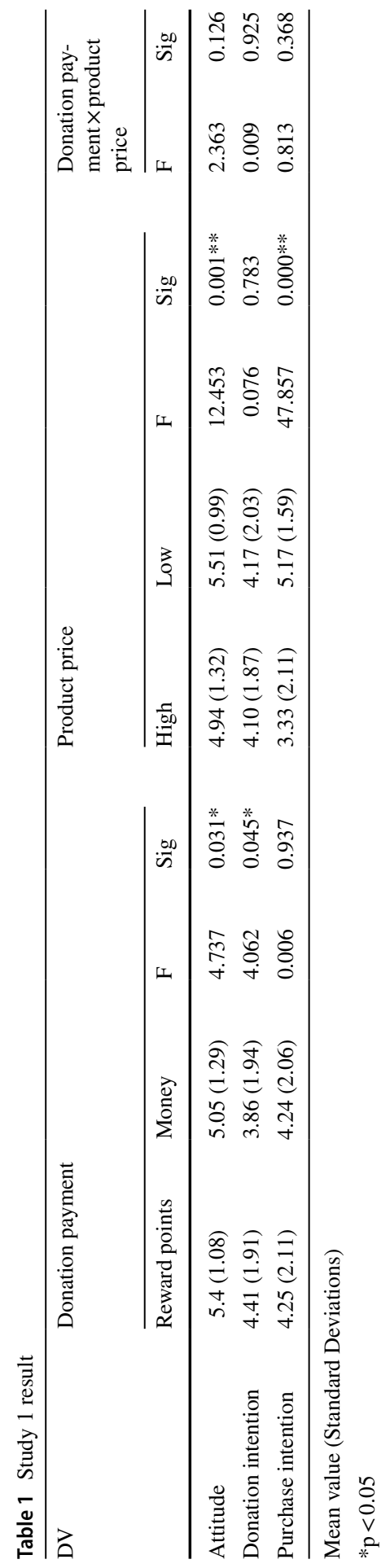


attitude toward the online retailer and higher donation intention, which supported the hypotheses. This result was in line with previous research that consumers were more likely to spend money when the pain of payment is decoupled and the mode of payment is less vivid (Raghubir \& Srivastava, 2009; Soman, 2001; Thaler, 1999). There was, however, no significant difference between reward points and money donation options on consumers' purchase intention. This could be because purchase intention is often strongly tied to product performance and value perception (Barone et al. 2007; Chang \& Wildt, 1994). In this study, consumers' purchase decision might have been influenced by their assessment of the quality of the product and value rather than donation payment options because the donation is not mandatory and is not integrated into the product price.

It is interesting to note that consumers showed a more favorable attitude and higher purchase intention with the lower price product in contrast to the initial expectation. Although prior research has suggested that consumers would be skeptical of the firm's effort and would not purchase a product when the donation amount is high compared to the product price (Hajjat, 2003; Strahilevitz, 1999; Tversky \& Kahneman, 1981), other researchers found conflicting results in that consumers showed higher purchase intention with lower price products with donation campaign (Kleber et al., 2016), which is consistent with our results. Researchers argued that consumers may consider the donation amount as a surcharge to the price when facing a high priced product and it would be better to make a direct donation, which counteracts the positive effects of CrM and reduces purchase intention (Baghi et al. 2010; Chang, 2008). The product price level did not show any difference on consumers' donation intention. Many empirical investigations demonstrated that online monetary donation behavior is strongly influenced by consumers' attitude, value, and previous experience associated with the cause (Sura et al. 2017; Choi et al., 2019). It is plausible that consumers' donation intention was more influenced by their personal differences than product price levels.

In contrast to $\mathrm{H} 3$, the rewards points donation was important to consumers' attitude and donation behavior regardless of product price level. Initially, it was expected that when a high price product was paired with the rewards points donation, it would elicit more favorable consumer attitudes and behavioral intention. This result indicates that the rewards points donation would work well with all range of price products.

\section{Study 2}

Study 2 was designed to test hypotheses 4-6. Given Study 1's findings that consumers showed more positive attitude and higher intention to donate when the donation option was suggested in reward points, Study 2 was to strengthen the findings from Study 1 and to explore the relations between the reward points option and consumers' attitude and behavior intention. Study 2 employed two different types of reward points (reward points that consumers previously earned vs. reward points that consumers will earn from future transactions) to see whether the current or future points will influence consumers' attitude and behavioral intention. Study 2 also included 
two different products (utilitarian vs. hedonic) to investigate whether the types of products influenced consumers' attitude at checkout charity.

\section{Method}

\subsection{Participants}

Out of total 200 participants, 196 people completed the survey in the Study 2 through Amazon MTurk. The research participants' ages ranged from 20 to 74 $(\mathrm{M}=41.98)$ with 97 male participants $(49.5 \%)$ and 99 female participants $(56.5 \%)$. In terms of age, $14.3 \%$ of the respondents were aged $20-30,40.8 \%$ were aged $31-40$, $20.5 \%$ were aged $41-50,16.3 \%$ were $51-60$, and $8.2 \%$ were over 61 years old.

\subsection{Design}

To investigate hypotheses 4-6, this study chose an experimental design. This study adopted a 2 (reward points type: previously earned points vs. expected future points) $\times 2$ (product type: utilitarian vs. hedonic) factorial between-group experimental design.

\subsection{Materials and procedure}

Four different online shopping checkout pages were created for Study 2. The checkout pages were designed using the same fictitious charity "COVID19 Relief Foundation" without a specific company name. Two different reward points options were given for the same value: 100 previously earned reward points and 100 expected future points that will be earned from the transaction. It was indicated that 100 points were equal to $\$ 1$. Two different products were given to investigate online consumers' responses to the donation suggestion at checkout: utilitarian product (36 rolls of toilet paper) and hedonic product (two dozen red roses). The price for both products was set at $\$ 49.99$ and which also reflected the actual market price of 36 rolls toilet paper and two dozen red roses. At the time of the experiment, 36 rolls of Charmin brand toilet paper was sold for $\$ 48.45$ on Amazon.com. Two dozen red roses were also sold for $\$ 49.99$ on $1-800$-flowers.com. To avoid familiarity effect from the well-known brands, both products were presented without a specific brand name.

The online survey link was shared on Amazon MTurk. Participants were asked to read a scenario about online shopping for practical items such as toilet paper or items for pleasure such as flowers. After reading the scenario, participants were asked to imagine that they would buy the product they saw and started the checkout process. They were then randomly assigned to one of four checkout pages. One of the four checkout pages was randomly presented with its donation option as either current reward points or future reward points and product type as utilitarian product (toilet paper) or hedonic product (roses) at the same value of \$49.99. Participants 
were asked to complete the survey questions for attitude toward the online retailer, donation intention, and purchase intention.

\subsection{Measures}

The same measurement items were used from the Study 1. All measurement items had their internal consistency examined by Cronbach's $\alpha$ coefficients analysis. Attitude toward an online retailer $(\alpha=0.965)$, donation intention $(\alpha=0.970)$, and purchase intention $(\alpha=0.982)$ all showed a Cronbach's $\alpha$ higher than $0.8(\alpha>0.8)$, which exceeds the threshold and is considered good (Cortina, 1993).

\subsection{Manipulation check}

Independent samples t-tests were conducted to verify hedonic and utilitarian product classification. Participants were asked to evaluate each product to verify the utilitarian and hedonic nature of the two products as intended. Three items to measure hedonic/utilitarian nature were adapted from the study by Wakefield and Inman (2003). The participants were asked to rate the product on the semantic differential scale of "practical purpose (1)/just fun (7)," "pure function (1)/pure enjoyment (7)," and "routine need (1)/pleasure (7)." Results showed that participants assessed the utilitarian product (toilet paper) significantly more practical and functional than the hedonic product (roses). The participants judged that toilet paper is utilitarian $(\mathrm{M}=1.40, \mathrm{SD}=1.13)$ while red roses is hedonic $(\mathrm{M}=5.96, \mathrm{SD}=1.25)$, $t(194)=26.74, p<0.001$. Thus, the stimuli were appropriately manipulated.

\section{Results}

Study 2 adopted a 2 (reward points type: previously earned points vs. expected future points) $\times 2$ (product type: utilitarian vs. hedonic) two way ANOVA to test hypotheses (Table 2).

Hypothesis 4 expected that suggesting to donate currently owned reward points will have more favorable attitude ( $\mathrm{H} 4 \mathrm{a})$, higher donation intention $(\mathrm{H} 4 \mathrm{~b})$, and higher purchase intention $(\mathrm{H} 4 \mathrm{c})$ than suggesting to donate future reward points. The result shows that there are no significant main effects of reward points type on attitude ( $F$ $(1,192)=0.44, p>0.05)$, donation intention $(\mathrm{F}(1,192)=0.64, p>0.05)$, and purchase intention $(\mathrm{F}(1,192)=0.92, p>0.05)$ rejecting $\mathrm{H} 4$.

Hypothesis 5 assumed that suggesting a checkout donation when purchasing a hedonic product will induce a more favorable attitude (H5a), higher donation intention $(\mathrm{H} 5 \mathrm{~b})$, and higher purchase intention $(\mathrm{H} 5 \mathrm{c})$ than purchasing a utilitarian product. No significant main effect was found on attitude $(\mathrm{F}(1,192)=3.33, p>0.05)$, donation intention $(\mathrm{F}(1,192)=0.07, p>0.05)$, and purchase intention $(\mathrm{F}(1$, $192)=0.20, p>0.05)$. Thus, H5 is not supported.

Hypothesis 6 predicted that when online consumers were offered to donate their currently owned reward points with hedonic product purchase, they would 


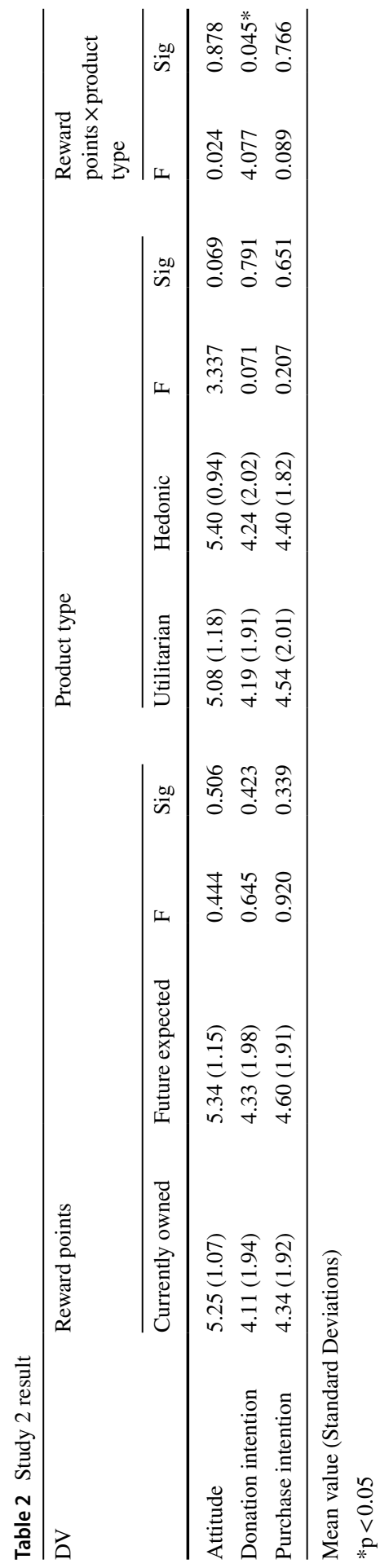




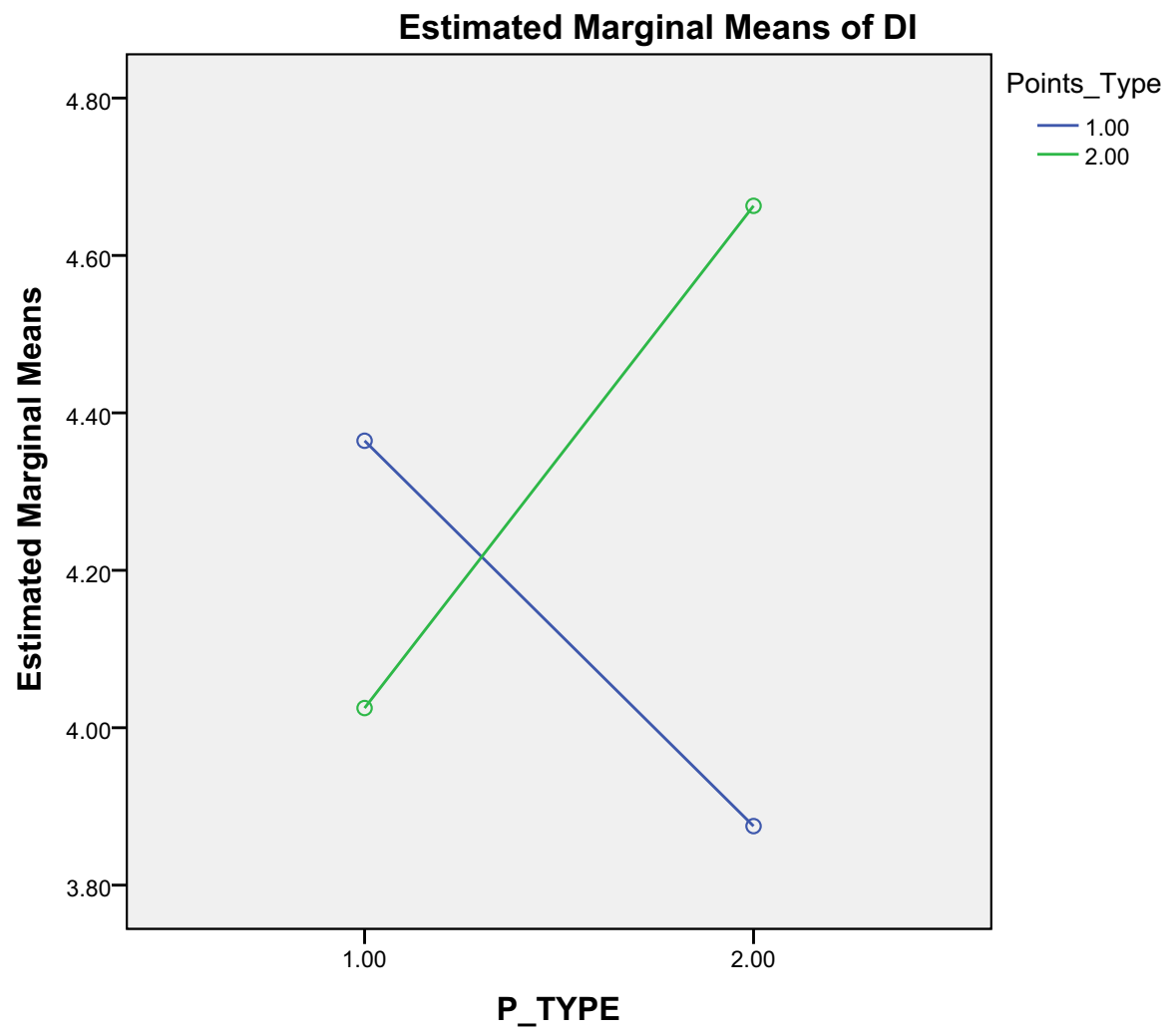

Fig. 1 Donation intention

show more favorable attitude, donation intention, and purchase intention than when donating future reward points with utilitarian product purchase (Fig. 1). The result demonstrated a statistically significant interaction effect between the reward points type and the product type for the donation intention $(F(1,192)=4.07$, $p<0.05)$. The interesting finding was that consumers showed a higher donation intention when offered the opportunity to donate $n$ future points $(M=4.66$, $\mathrm{SD}=1.95)$ rather than current points $(\mathrm{M}=3.87, \mathrm{SD}=2.01)$ when purchasing a hedonic product, contrary to the expectation. Meanwhile, there was no interaction effect between points type and product type on attitude $(\mathrm{F}(1,192)=0.02$, $p>0.05)$ and purchase intention $(\mathrm{F}(1,192)=0.20, p>0.05)$. Hence, H6 is not supported. 


\section{Discussions}

The result of the Study 2 showed that the difference between current reward points earned from previous transaction and future reward points that will be earned from the current transaction did not elicit differences in consumers' attitude, donation intention, and purchase intention. The result implies that a checkout charity solicitation in reward points influences consumers' perception and behavioral intention equally regardless of when the points were earned, which is contrary to the hypothesis. One plausible explanation is that consumers might have perceived the value of the previously acquired reward points as the same as the potential new reward points because consumers would have been reminded of the points value when they were approached to donate. While several studies indicated that people tend to regard advanced purchases as free, when the previously acquired good is not consumed as planned, the cost of the good appears salient again (Liu \& Chiu, 2015; Shafir \& Thaler, 2006). Consumers often redeem accumulated reward points when shopping to lower their actual money spending. They might have forgotten about the previously earned reward points but the value of the reward points could be resuscitated when they were asked to donate instead of redeeming for shopping.

Results found no significant difference between utilitarian product and hedonic product on online consumers' attitude, donation intention, and purchase intention, in contrast to H5. Although Study 2 did not find a convincing effect of the hedonic product on checkout donation, a similar finding was also noted in that the hedonic product did not induce a more favorable attitude to CrM campaign or purchase intention (Chang, 2011). It is believed that consumers tend to donate to reduce their guilt when buying non-necessary products, but individuals who are less prone to guilt may not experience the same kind of guilty feeling when purchasing hedonic products (Tangney, 1990). Furthermore, the effectiveness of checkout donation might be associated with pressure rather than consumers' motivation to donate (Kinard \& Padro, 2017), so consumers may have not experienced the same level of guilt and pressure in an online checkout donation when there is no cashier or other people waiting behind of them.

A notable finding of this study is that hedonic products with a future reward points donation option induces online consumers' higher donation intention than the currently held reward points. That is, consumers are more likely to donate the expected future reward points that will be earned from the hedonic product purchase. Prior research has suggested that consumers find CrM more attractive when the donation is presented in a combined and integrated format (e.g., product $\mathrm{X}$ price $\$ 100$ of which 5\% is donated to support a charity) in the case of purchasing hedonic products because it reduces consumers' guilt of purchasing hedonic products (Baghi et al. 2010). Thus, a possible explanation for our study result is that consumers were more likely to donate the future reward points that would be accrued from the hedonic product purchase to shake off the guilty feeling of pleasure shopping, rather than previously earned reward points that are not the result of hedonic product shopping. 


\section{General discussion}

The goal of the study was to examine how consumers' mental accounting would influence their intention to donate in online checkout charity. The findings contribute to the existing research on checkout charity by examining the role of reward points on consumers' attitude and behavioral intention based on mental accounting theory.

First, the results confirm the significant impact of consumers' mental accounting on their intention to donate at checkout charity. Suggesting a donation in reward points instead of money elicited more favorable attitudes and increased consumers' donation intention, thus supporting earlier studies that found consumers were more likely to spend money when they believe the money is "play money" or "free" because the payment would be less painful in parting from the money (Arkes et al. 1994; Liu \& Chiu, 2015; Raghubir \& Srivastava, 2009). Hence, consumers would be more favorable toward the online retailer that requests donation in reward points that felt like "free" as they don't have to fork over their hard-earned money and were more likely to donate at checkout charity.

Second, this study suggests that consumers would be more likely to donate expected future reward points that will be earned from online shopping when buying a hedonic product. This finding supports Baghi et al.'s (2010) integrated mental accounting study, whereby consumers feel more positively about CrM when the product and the donation is combined and presented as one event, but only for hedonic products. The integrated format provides donation and a hedonic product purchase in one event, which reduces consumers' guilty feeling of buying a product that has no practical value. Regarding this study, it can be inferred that consumers would donate the expected future reward points that are the direct result of hedonic product shopping to reduce their guilt.

The empirical findings of the current study provide important implications for marketing practitioners involved in checkout charity campaigns. This study showed that requesting that consumers donate reward points instead of money can improve consumers' donation behavior significantly due to consumers' mental accounting. This indicates that the checkout charity result can be improved by opting for checkout charity that requests donations in reward points. Although numerous retailers offer customer rewards program, few retailers offer checkout charity in reward points. Providing additional options to redeem their earned reward points for a donation makes consumers feel positive about the retailers.

Practitioners could offer the option of donating the future reward points that would be accrued from the purchase to reduce consumers' guilt if the retailer sells hedonic products. Consumers psychologically earn "moral credit" when they donate; it gives consumers license to do something not virtuous like spending money on non-essential products (Giebelhausen et al. 2017). Consumers would find the option to donate reward points that are the result of frivolous shopping to be comforting in reducing their guilt and increasing their willingness to donate.

It should also be considered that we cannot assume that consumers who buy more expensive products are not necessarily more generous in donating. Based on 
the study finding, consumers' donation intention was not associated with product price, whereas purchase intention was more associated with product price.

This suggests that checkout charity would be an excellent choice for improving consumers' attitude toward the retailer and increasing donations for charities by utilizing the reward points option but might not be the best option to increase sales.

The current study has several limitations that need to be addressed. First, this study adopted "COVID19 Relief Foundation" as a fictitious charity to request checkout charity. There may be different responses for the charity donation request based on consumers' prior attitude and experience associated with the cause (Sura et al. 2017; Choi et al., 2019). Certain crises that are blameless and relatable to the general population elicit intense community response and trigger altruism (Ellen et al. 2000; Hawdon et al. 2012; Obeng et al. 2019). Because everyone in the world has experienced COVID-19, this may have influenced consumers' sympathy, altruism, and donation intention. Future studies should include more diverse causes and also examine respondents' prior attitude and involvement with charities.

Second, the Study 1 included only one product (a pair of jeans) to measure consumers' donation response when requesting a donation in reward points. The participants may have responded differently depending on their actual interest in buying the product although the scenario asked them to think they needed to purchase a new pair of jeans. The future study should include diverse set of retailers and products (e.g., grocery store, pharmacies) to strengthen the findings.

Third, this study was conducted based on internet website stimuli that excluded brand names and may have influenced consumers' attitude and responses. Future studies should consider conducting similar studies in a real online retailer environment including different amount of accumulated reward points and expiration date to corroborate this study findings.

\section{Conclusion}

Applying mental accounting theory (Thaler, 1985, 1999), this study conducted online experiments to examine the impact of donation payment methods, product price, and product type on consumers' attitude and behavioral intention toward online checkout charity. Overall, this study demonstrated that requesting a donation in reward points would enhance consumers' attitude toward the retailer and their intention to donate at online checkout charity. The result also showed that consumers who are purchasing a hedonic product are more likely to donate the expected future rewards from the transaction than previously earned reward points. The product price and product type did not produce significant differences on consumers' donation intention.

This study finding has practical implications for marketing practitioners involved in checkout charity campaigns, such as implementing reward points donation options at online retailer checkout charity. This study showed that the consumers are more willing to donate their retailer reward points than their money. Also requesting the donation of expected future reward points rather than previously accrued reward 
points could increase consumers' donation as it can reduce consumers' guilt of buying hedonic products.

Funding Funding was provided by Kean University (Garnt No. UFRI Grants AY 2020-2021).

\section{References}

Adkins, S. (2012). Cause-related marketing: Who cares wins (pp. 699-723). Routledge.

Arkes, H. R., Joyner, C. A., Pezzo, M. V., Nash, J. G., Siegel-Jacobs, K., \& Stone, E. (1994). The psychology of windfall gains. Organizational Behavior and Human Decision Processes, 59, 331-347.

Austin, J. E. (2000). Strategic collaboration between nonprofits and businesses. Nonprofit and Voluntary Sector Quarterly, 29(1), 69-97.

Baghi, I., Rubaltelli, E., \& Tedeschi, M. (2010). Mental accounting and cause related marketing strategies. International Review on Public and Nonprofit Marketing, 7(2), 145-156.

Barone, M. J., Miyazaki, A. D., \& Taylor, K. A. (2000). The influence of cause-related marketing on consumer choice: Does one good turn deserve another? Journal of the Academy of Marketing Science, 28(2), 248-262.

Barone, M. J., Norman, A. T., \& Miyazaki, A. D. (2007). Consumer response to retailer use of causerelated marketing: Is more fit better? Journal of Retailing, 83(4), 437-445.

Berinsky, A. J., Huber, G. A., \& Lenz, G. S. (2012). Evaluating online labor markets for experimental research: Amazon. com's Mechanical Turk. Political Analysis, 20(3), 351-368.

Bower, A. B., \& Landreth, S. (2001). Is beauty best? Highly versus normally attractive models in advertising. Journal of Advertising, 30(1), 1-12.

Chandran, S., \& Morwitz, V. G. (2005). Effects of participative pricing on consumers' cognitions and actions: A goal theoretic perspective. Journal of Consumer Research, 32(2), 249-259.

Chang, C. T. (2008). To donate or not to donate? Product characteristics and framing effects of causerelated marketing on consumer purchase behavior. Psychology \& Marketing, 25(12), 1089-1110.

Chang, C. T. (2011). Guilt appeals in cause-related marketing: The subversive roles of product type and donation magnitude. International Journal of Advertising, 30(4), 587-616.

Chang, C. T., \& Chu, X. Y. M. (2020). The give and take of cause-related marketing: Purchasing causerelated products licenses consumer indulgence. Journal of the Academy of Marketing Science, 48(2), 203-221.

Chang, T. Z., \& Wildt, A. R. (1994). Price, product information, and purchase intention: An empirical study. Journal of the Academy of Marketing Science, 22(1), 16-27.

Charitynavigator. (2020). Should you feel good about donating at checkout? Retrieved March 05, 2021, from https://blog.charitynavigator.org/2020/01/should-you-feel-good-about-donating-at.html.

Choi, S., Mattila, A. S., \& Quadri-Felitti, D. (2019). Donation appeals rewarding fitness in the context of CSR initiatives. Journal of Services Marketing, 33(2), 160-167

Cortina, J. M. (1993). What is coefficient alpha? An examination of theory and applications. Journal of Applied Psychology, 78(1), 98

Dunn, E. W., \& Norton, M. I. (2013). Happy money: The science of smarter spending. Simon and Schuster.

Ellen, P. S., Mohr, L. A., \& Webb, D. J. (2000). Charitable programs and the retailer: Do they mix? Journal of Retailing, 76(3), 393-406.

Engage for Good. (2020). Charity Checkout Champions 2019. Engage for Good. Retrieved from https:// engageforgood.com/ccc_2019_download/.

Giebelhausen, M., Lawrence, B., \& Chun, H. H. (2020). Doing good while behaving badly: Checkout charity process mechanisms. Journal of Business Ethics, 1-17.

Giebelhausen, M., Lawrence, B., Chun, H. H., \& Hsu, L. (2017). The warm glow of restaurant checkout charity. Cornell Hospitality Quarterly, 58(4), 329-341.

Good Scout. (2016). Change at the checkout: The evolution of charitable donations at the register. Good Scout. Retrieved August 21, 2020, from http://engageforgood.com/wp-content/uploads/2016/11/Chang eatCheckout_FinalReport.pdf. 
Gupta, S., \& Pirsch, J. (2006). A taxonomy of cause-related marketing research: Current findings and future research directions. Journal of Nonprofit \& Public Sector Marketing, 15(1-2), 25-43.

Hajjat, M. M. (2003). Effect of cause-related marketing on attitudes and purchase intentions: The moderating role of cause involvement and donation size. Journal of Nonprofit \& Public Sector Marketing, 11(1), 93-109.

Hawdon, J., Oksanen, A., \& Räsänen, P. (2012). Media coverage and solidarity after tragedies: The reporting of school shootings in two nations. Comparative Sociology, 11(6), 845-874.

Heath, C., \& Soll, J. B. (1996). Mental budgeting and consumer decisions. Journal of Consumer Research, 23(1), 40-52.

Kelly, B. (1991). Cause-related marketing: Doing well while doing good. Sales and Marketing Management, 143(3), 60-65.

Kinard, B. R., \& Pardo, M. L. (2017). Cause-related marketing: The effect of checkout charity requests on consumer donation behavior. Atlantic Marketing Journal, 6(2), 77-91.

Kleber, J., Florack, A., \& Chladek, A. (2016). How to present donations: The moderating role of numeracy in cause related marketing. Journal of Consumer Marketing, 33(3), 153-161

Kotler, P., \& Lee, N. (2005). Best of breed: When it comes to gaining a market edge while supporting a social cause, “corporate social marketing” leads the pack. Social Marketing Quarterly, 11(3-4), 91-103.

Lantos, G. P. (2014). Marketing to millennials: Reach the largest and most influential generation of consumers ever. Journal of Consumer Marketing, 31(5), 401-403.

Leonidou, C. N., \& Skarmeas, D. (2017). Gray shades of green: Causes and consequences of green skepticism. Journal of Business Ethics, 144(2), 401-415.

Liu, H. H., \& Chiu, Y. Y. (2015). Sales framing, mental accounting, and discount assignments. Asia Pacific Management Review, 20(4), 201-209.

Mitchell, A. A., \& Olson, J. C. (1981). Are product attribute beliefs the only mediator of advertising effects on brand attitude? Journal of Marketing Research, 18(3), 318-332.

Mullen, J. (1997). Performance-based corporate philanthropy: How "giving smart" can further corporate goals. Public Relations Quarterly, 42(2), 42.

Murray, D. (2017). Checkout charities contribute millions to good causes, but use caution when donating. Great Falls Tribune. Retrieved August 21, 2020, from https://www.greatfallstribune.com/story/news/ 2017/11/20/checkout-charities-contribute-millions-good-causes-use-caution-when-donating/88089 $8001 /$.

Nakhata, C., \& Dugan, R. (2017). A little for me, a lot for you: the relationship between checkout charity and gratuity size (An Abstract). In Creating marketing magic and innovative future marketing trends. Springer. https://doi.org/10.1007/978-3-319-45596-9_3.

Nan, X., \& Heo, K. (2007). Consumer responses to corporate social responsibility (CSR) initiatives: Examining the role of brand-cause fit in cause-related marketing. Journal of Advertising, 36(2), 63-74.

Obeng, E., Nakhata, C., \& Kuo, H. C. (2019). Paying it forward: The reciprocal effect of superior service on charity at checkout. Journal of Business Research, 98, 250-260.

Park, E., Kim, K. J., \& Kwon, S. J. (2017). Corporate social responsibility as a determinant of consumer loyalty: An examination of ethical standard, satisfaction, and trust. Journal of Business Research, 76, 8-13.

Polonsky, M. J., \& Macdonald, E. K. (2000). Exploring the link between cause-related marketing and brand building. International Journal of Nonprofit and Voluntary Sector Marketing, 5(1), 46-57.

Prelec, D., \& Loewenstein, G. (1998). The red and the black: Mental accounting of savings and debt. Marketing Science, 17(1), 4-28.

Putrevu, S., \& Lord, K. R. (1994). Comparative and noncomparative advertising: Attitudinal effects under cognitive and affective involvement conditions. Journal of Advertising, 23(2), 77-91.

Raghubir, P., \& Srivastava, J. (2008). Monopoly money: The effect of payment coupling and form on spending behavior. Journal of Experimental Psychology: Applied, 14(3), 213.

Raghubir, P., \& Srivastava, J. (2009). The denomination effect. Journal of Consumer Research, 36(4), $701-713$.

Roos, D. (2018). Where's the money going when you 'round up for charity' at the cash register? Howstuffworks. Retrieved August 21, 2020, from https://money.howstuffworks.com/checkout-charity-is-goodfor-business.htm.

Schleider, J. L., \& Weisz, J. R. (2015). Using Mechanical Turk to study family processes and youth mental health: A test of feasibility. Journal of Child and Family Studies, 24(11), 3235-3246.

Shafir, E., \& Thaler, R. H. (2006). Invest now, drink later, spend never: On the mental accounting of delayed consumption. Journal of Economic Psychology, 27(5), 694-712.

Shefrin, H. M., \& Thaler, R. H. (1988). The behavioral life-cycle hypothesis. Economic Inquiry, 26(4), 609-643. 
Soman, D. (2001). Effects of payment mechanism on spending behavior: The role of rehearsal and immediacy of payments. Journal of Consumer Research, 27(4), 460-474.

Soman, D. (2004). Framing, loss aversion, and mental accounting. Blackwell Handbook of Judgment and Decision Making, 379-398.

Soster, R. L., Gershoff, A. D., \& Bearden, W. O. (2014). The bottom dollar effect: The influence of spending to zero on pain of payment and satisfaction. Journal of Consumer Research, 41(3), 656-677.

Strahilevitz, M. (1999). The effects of product type and donation magnitude on willingness to pay more for a charity-linked brand. Journal of Consumer Psychology, 8(3), 215-241.

Strahilevitz, M., \& Myers, J. G. (1998). Donations to charity as purchase incentives: How well they work may depend on what you are trying to sell. Journal of Consumer Research, 24(4), 434-446.

Strauss, W., \& Howe, N. (2000). Millennials rising: The next great generation. Vintage Books.

Sura, S., Ahn, J., \& Lee, O. (2017). Factors influencing intention to donate via social network site (SNS): From Asian's perspective. Telematics and Informatics, 34(1), 164-176.

Szykman, L. R., Bloom, P. N., \& Blazing, J. (2004). Does corporate sponsorship of a socially-oriented message make a difference? An investigation of the effects of sponsorship identity on responses to an antidrinking and driving message. Journal of Consumer Psychology, 14(1-2), 13-20.

Tangney, J. P. (1990). Assessing individual differences in proneness to shame and guilt: Development of the Self-Conscious Affect and Attribution Inventory. Journal of Personality and Social Psychology, 59(1), 102.

Thaler, R. (1980). Toward a positive theory of consumer choice. Journal of Economic Behavior \& Organization, 1(1), 39-60.

Thaler, R. (1985). Mental accounting and consumer choice. Marketing Science, 4(3), 199-214.

Thaler, R. (1999). Mental accounting matters. Journal of Behavioral Decision Making, 12(3), 183-206.

Thomas, M., Desai, K. K., \& Seenivasan, S. (2011). How credit card payments increase unhealthy food purchases: Visceral regulation of vices. Journal of Consumer Research, 38(1), 126-139.

Till, B. D., \& Nowak, L. I. (2000). Toward effective use of cause-related marketing alliances. Journal of Product \& Brand Management, 9(7), 472-484.

Tversky, A., \& Kahneman, D. (1981). The framing of decisions and the psychology of choice. Science, 211(4481), 453-458.

Varadarajan, P. R., \& Menon, A. (1988). Cause-related marketing: A coalignment of marketing strategy and corporate philanthropy. Journal of Marketing, 52(3), 58-74.

Wakefield, K. L., \& Inman, J. J. (2003). Situational price sensitivity: The role of consumption occasion, social context and income. Journal of Retailing, 79(4), 199-212.

Youn, S., \& Kim, H. (2008). Antecedents of consumer attitudes toward cause-related marketing. Journal of Advertising Research, 48(1), 123-137.

Zellermayer, O. (1996). The pain of paying. unpublished dissertation, Department of Social and Decision Sciences. Carnegie Mellon University.

Zemack-Rugar, Y., Rabino, R., Cavanaugh, L. A., \& Fitzsimons, G. J. (2016). When donating is liberating: The role of product and consumer characteristics in the appeal of cause-related products. Journal of Consumer Psychology, 26(2), 213-230.

Publisher's note Springer Nature remains neutral with regard to jurisdictional claims in published maps and institutional affiliations. 